\title{
Welcome to the Sitcom School: A Globalized Outlook for the Study of Television History
}

\author{
Sharon Shahaf \\ Department of Radio, Television and Film \\ University of Texas at Austin
}

\author{
Keywords Israeli Television, Global Television Formats, Krovim-Krovim, \\ Israeli Educational Television
}

\begin{abstract}
Extending back the insight offered by the emerging framework of global television formats, this article examines the production and public reception of the first Israeli sitcom, Krovim-Krovim, produced by Israeli Educational Television (IETV) between 1982 and 1986. As the first fullblown Israeli series and a show modeled on the globally popular sitcom formula, Krovim-Krovim was simultaneously celebrated for its Israeliness and condemned as a potential source of Western 'cultural contamination'. The concerns converging around Krovim-Krovim in 1980s Israel are representative of a larger global trend in that period that witnessed 'the second wave of globalization'. The simplistic media imperialism scenario that still dominates scholarship of these trends fails to grasp the complexities typifying the process of globalization. Representing as they do simultaneous standardization and heterogenization of form and content across borders, global television formats seems to embody these complexities. By reevaluating IETV's sitcom production as an early case of format adaptation this article demonstrates the promises of this fresh outlook for the study of historical as well as contemporary trends in television globalization. By foregrounding the perspective of 'local' producers and critics, this article explores the cultural significance of format adaptation for marginal and belated broadcast systems - like 1980s Israeli television.
\end{abstract}

\section{Introduction}

In October 1981, an Israeli Educational Television (IETV) crew travelled to Los Angeles for professional training in sitcom production on the set of Three's Company. By then, this Israeli public-television 'dream team' was in the advance stages of pre production for the first ever Israeli sitcom - Krovim-Krovim (Near Ones and Dear Ones). It was also the first ever Israeli multi-seasonal series broadcast for three seasons between 1983 and 1986. While the Israeli General Broadcasting Authority Television (IBA) that shared the single state channel with IETV had been importing American and British made sitcoms, dramas, and prime-time soaps since the 1970s, IETV- the bold 'little sister' station originally designed as an

Westminster Papers in Communication and Culture (C) 2007 (University of Westminster, London), Vol. 4(4): 103-123. ISSN 1744-6708 (Print); 1744-6716 (Online) 
instructional service for schoolchildren - was the first to take up a globally popular television formula as model for local drama series production. ${ }^{1}$

As the first full-blown Israeli series, Krovim-Krovim has been most commonly celebrated for its 'Israeliness' - or its distinct portrayal and representation of Israeli national culture and identity. To this day the show is generally celebrated in Israeli mainstream discourse as symbolizing the 'good old Israeli' identity of more simple times. As the PR person for an Israeli bank who sponsored a special reunion episode in 2004 put it, 'Krovim-Krovim epitomizes Israeliness at its finest' (Ynet.com 2004). ${ }^{2}$

Initially IETV's venture was viewed by many as a positive and much anticipated counter balance to the inflow of American and British television imports that were saturating the Israeli screen (Almog 2004). However, while celebrating KrovimKrovim's Israeliness, the critics simultaneously positioned the discussion of the show in relation to the programmes that were the model for its production. On the one hand the contrast was used to praise the locality of the show's content. On the other hand, however, the textual conventions, writing style, acting performances and production values of the imported programmes were simultaneously held up as the norm by which the local series was evaluated and understood. Yediot Aharonot journalist Naomi Gal, for instance, greeted the show enthusiastically:

Congratulations. We finally have... an original series of our own...It doesn't deal with rich Texan families...Manhattan teenagers, or anorectic blonds... It is taken directly from the reality of our lives and mirrors it...the characters speak Hebrew, their problems are the same as yours and mine...The background: an apartment building with a simple dining table like we have in our kitchen...an Israeli manufactured refrigerator, Hebrew books, plants that fit our climate, in short: an Israeli series... (Gal 1983, 16)

In the competing Ma'ariv, Gil Kaisary both joined in on the celebration of the show's authentic representation of Israeliness and argued enthusiastically that it was bound to create a similar relationship with its audiences to that created by American television programmes:

The Israeli viewing audience is expected to meet regularly... with (the new cast of characters). An encounter... similar to encounters of the popular kind with the household members of Archie Bunker, Benson, and the soap variety. However, this time the humour is ours, the jokes are in blue and white and...belong to the cultural heritage of the people of the book... Thus we will no longer need to envy the Americans for having such a successful popular product like Archie Bunker. From now on we prove we have the ability to produce creations of an equal quality, and maybe even better...(Kaisary 1983, 3). 


\section{Shahaf, Welcome to the Sitcom School...}

Competing as it did on a playing field defined by the dominant U.S and U.K television imports the show, celebrated so much for its Israeliness, was simultaneously debated as a product of Western cultural influence. Thus, while Kaisary obviously favours the show's success in fulfilling the American model others find this to be a cause for concern. As Michael Ohad, a journalist in the highbrow daily Ha'aretz put it:

The argument that will rise (once the show is broadcast) will not revolve around the performance, which is brilliant, but around the very idea (my emphasis). For years Israeli critics deplored the imported hilarities from the U.S and the U.K. - Could the 'chosen people' who set forth Jeremiah the prophet... and Albert Einstein, take part in 'Goyim-Naches'3 like the LoveBoat? (Ohad 1982, 16)

Ohad's critique reveals the uneasiness within Israeli public discourse of the time regarding the relationship between adapted 'foreign' or imported television entertainment formats and 'appropriate' Israeli national culture. Anticipating similar concerns and critiques for Krovim-Krovim Kaisary concludes:

Why should we complain, in as much as the primary goal, the main objective, the very raison d'être of the televisual medium is a regular encounter, as wide as possible, with the greatest number of viewers. KrovimKrovim stands the chance of fulfilling this ambition. (Kaisary 1983, 3).

This apologetic justification of Krovim-Krovim's anticipated popularity in terms of what television's raison d'être 'really is' emphasizes the fact that in 1980s Israel things were still perceived quite differently. Unlike the commercial context shaping the production and reception of American television, IETV as a subdivision of the Israeli Ministry of Education negotiated very different cultural and institutional circumstances. Consequently, the debates and discourses shaping the production, text, and public reception of Krovim-Krovim revolved around a very different set of issues and concerns than those shaping contemporary debates on British or American sitcoms.

Looking at Krovim-Krovim's production processes and public reception, this article aims to explore the particular set of organizational, ideological, financial, aesthetical, national and educational constraints shaping this televisual event. This will illustrate the concrete manner in which seemingly abstract processes of cultural globalization through the dissemination of an 'Americanized' media culture occur. Furthermore, by looking at Krovim-Krovim, I wish to demonstrate the deeply hybrid nature of this process and the inherent contradictions that are manifest in it, as the production processes are deeply embedded in both the 'global' and the 'local'. In this case, these dimensions are locally understood as tensions between the dissemination of a dominant Western TV cultural form, and the seemingly 
contradictory processes of Israeli nation-building, through the production of a televised artefact that will reflect and shape local national identity and culture.

These contradictions are now at the cutting edge of global television studies discussions surrounding the relatively unexplored and under theorized phenomenon of global television formats. Extending back this exciting new framework for the understanding of media globalization, this article points out its importance not only for research into contemporary global television trends, but also in the re-evaluation of related historical instances.

\section{The Sitcom as Global Television Format}

The concerns converging around Krovim-Krovim in 1980s Israel are in fact representative of a larger global trend in the historical period that witnessed the emergence of what Stuart Hall terms, 'the second wave of globalization' (Hall 1997). According to Hall, while the first wave of global integration was dominated by the rise of nation states and imposed through European colonialism, the second wave, beginning gradually after World War Two, is typified by a post-national trend, and governed by the economical and cultural dominance of the U.S. (Ibid).

Hall, as well as others has noted that this epoch of Americanized globalization is connected at its core to the rise of an American-centred global media culture (Schiller 1992; Sreberny-Mohammad et al 1997; Kellner 2002). While scholarship looking at these media trends in the 1980s was dominated by the media imperialism approach, this oversimplified scenario fails to grasp the complexities involved in the second wave of globalization as theorized by Hall and others (for example: Hall 1997; Sreberny-Mohammad et al 1997; Kellner 2002; Parks and Kumar 2003).

Focusing as it did on the global expansion of U.S run multi-national media corporations and foregrounding the worldwide circulation of finalized or 'canned' U.S shows like Dallas, the one-sided media imperialism scenario fails to account for the complexities typifying the cultural and economical processes of globalization - mainly the tension between simultaneous global 'McDonaldization' or homogenization and the seemingly contradictory process of global heterogenization, or the 'persistence' of 'difference', and of local forms of identification globally (Hall 1997; Kellner 2002 ).

As I have previously mentioned, a new emerging debate in global television studies which is extremely helpful and relevant for the study of these complexities is the issue of global television formats (Oren and Shahaf forthcoming; Moran 1998; Waisbord 2005; Navarro 2006; Keane et al 2007). A staple of contemporary schedules everywhere, global television formats are generally defined in the 


\section{Shabaf, Welcome to the Sitcom School...}

international television industry as popular programming formulae - like 'Idol', 'Survivor' and 'Millionaire' - that get adapted, franchised, bought, mimicked, or stolen, and produced by local producers in multiple localities around the world (Oren and Shahaf forthcoming).

However the global dissemination and adaptation of popular (mostly Western) television forms, formulae, 'programming ideas', or 'genres' is not in itself new. In fact television systems have always engaged in official and unofficial transnational textual, formal and industrial exchanges (Oren and Shahaf forthcoming). Looking at these exchanges through the prism of format adaptation would benefit global television studies as this phenomenon represents a much more nuanced scenario of media globalization then the one offered by media imperialism.

Produced locally and based on an imported, most often (but not always) Western formula, global television formats seem to embody the paradoxes of globalization as they suggest a simultaneous standardization and heterogenization of both form and content in global television (Waisbord 1995; Keane 2007; Oren and Shahaf forthcoming). This phenomenon corresponds so well to the contradictory nature of contemporary globalized media-scapes that for some it now constitutes an alternative model for media globalization (Keane et al 2007).

However, extending back the insight offered by the GTF debate, this article will demonstrate the promise of this fresh outlook for the study of historical as well as contemporary trends in television globalization. Thus, while the scholarly framework is indeed new, the present study contends that the phenomenon itself has been around for much longer. Looking back at earlier cases of global formal television flows can help demonstrate the fundamental transnational nature of the medium of television still largely ignored in Western-centric television studies and historical and theoretical accounts.

\section{Formats and Global Cultural Domination}

One of the primary implications of the global television format debate relates to the question of media and global power relations. The contradictory nature of format adaptations makes it extremely tricky to account for the power relations involved. Most scholarly accounts of the phenomenon are still fraught with language reflecting simplistic media imperialism scenarios. Particularly prevalent are reductive binary discourses of 'globalization from above'.

In this discourse globalization is positioned as an inherently external economic process imposed on marginal societies 'from above' while the 'local' responses are perceived as 'internal' and inherently cultural. This set of assumptions allocates agency in the process of globalization to faceless multinational corporations or to 
the abstract 'movement' or 'wave' of late Western capitalism. It thus positions non Western (or non U.S) societies as passive recipients on which globalization is imposed from 'above' through the expansion of Western financial, commercial, technological, and communication networks (Kellner 2002). Such conceptualization is responsible for much of the misleading binarism still structuring scholarly understanding of the relationship between the economic and the cultural dimension of globalization.

Even Stuart Hall, who articulated very early a more complex account of the ambivalent relationship between universialization and difference within globalization, still perpetuates this dominant scenario (Hall 1997). According to Hall, 'second wave' globalization finds it cannot proceed without learning to live with and work through difference (Ibid). Even though this formulation acknowledges the multivalent contradictory nature of current global realities it still problematically confers agency and intentionality in the process to a faceless wave of Western 'capital' that 'advances' as it 'absorbs' and 'recognizes' difference (Hall 1997).

A Similar conceptualization lays in the heart of much of the existing literature on global television formats. Even one of the more sophisticated contributions to this literature, Silvio Waisbord's seminal McTV - Understanding the Global Popularity of Television Formats (2004) seems to work within lingering 'globalization from above' perceptions. Even though Waisbord maintains that formats demonstrate how television is 'simultaneously both global and national', he still explains this happens because the medium is shaped by 'both the globalization of media economics and the pull of local and national cultures' (Ibid 360, my emphases). The implicit assumption here is that in format adaptations a pre-existing 'pure' national culture is negotiated through, and consequently compromised, contaminated or bastardized by foreign televisual forms.

Television itself emerges here as a Trojan horse, a treacherous and permeable social and cultural site, through which the advent of global capitalism is facilitated and abetted. But is this really the case? Couldn't there be a more subtle relationship within the adaptation process between processes of globalization, and the production of local cultural identity? Should national or local culture be pitted in binary opposition against global televisual forms? Are the interests governing the adaptation of GTF necessarily, always, inherently, and unvaryingly aligned with the interests of faceless 'global capital'? What role can local perceptions regarding the nature and role of television as a social medium play in negotiating these conflicting elements?

By focusing on 1980s Israeli society and television and more particularly on the story of Krovim-Krovim, this article seeks to flip the globalization homogenization/ 


\section{Shahaf, Welcome to the Sitcom School...}

difference argument on its head. Thus, I am not interested in asking 'what is the particularity that the wave of 'globalization' - represented by the global dissemination of American televisual forms - encounters and 'absorbs' as it 'washes over' 1980s Israel?'

Instead, I wish to ask - what are the particularities out of which the Krovim-Krovim broadcasters and producers operate as they create this show? What is the unique combination of 'local' and 'global', ideological, political, technical, aesthetic, and economic constraints or forces, that come together to shape their work and its meaning from their own multiple perspectives? In what ways did they negotiate the tension between IETV's 'cultural uplift' and integration missions of 'nationbuilding' and the expansion of a westernized regime of representation as represented by the popularity of the sitcom?

To explore the 'particularities' out of which IETV folks operated I will first present the context of 1980s Israeli television in relation to the wider social and cultural historical context shaping that turbulent decade in the country's history. As I will shortly demonstrate, the unique circumstances and constraints shaping the first Israeli sitcom resulted from the exceptional, if short, history of television in Israel, in which IETV plays a key role.

\section{0s Israeli Society, Television, and the Beginning of a Post-Zionist Era}

In her groundbreaking work on the history of Israeli television Tasha Oren demonstrates that the threat of unwanted 'foreign' cultural influences was at the centre of the Israeli television debate from day one (Oren 2004). In this debate perceptions of a proper Israeli national culture were juxtaposed with assumptions about the nature and perceived influence of television.

The myth, centring on Prime-Minister David Ben-Gurion's rejection of television in the early 1950s, played an important part in consolidating the hegemonic notion that the medium was unnecessary and inappropriate for the new national Jewish culture. In this hegemonic discourse television was perceived as an inherently Americanized, commercial, entertainment medium threatening to bring about a bourgeoisie consumer-culture, incompatible with the goals and socialist ideals of self-sacrifice and austerity prescribed by the dominant Zionist Labour party for the national revival of the people of the book (Ibid).

While the threat of Americanizing influences held off the development of television, Oren explains how another type of cultural threat, presented by surrounding Arab culture, finally tilted the scale in favour of the development of an Israeli television service. This threat was strongly linked with the 'cultural integration problem' or, more specifically, the ethnic tension between Ashkenazim 
(Western or European Jews) and Mizrahim (Jews who immigrated to Israel from Muslim and Arab countries).

This tension emerged immediately after the period of mass immigration mainly from Morocco, Yamane, and Iraq, between 1948 and 1954 (Yosef 2004, 84). The ethnic identity of the newcomers and their cultural affinity with their Arab societies of origin threatened the Eurocentric nature of the national identity that the established Ashkenazi elite was trying to forge (Oren 1999, 21.) In this context concerns were raised that Mizrahi reception of Arab television transmissions, especially of popular culture, would help maintain this population's undesirable cultural identity (Oren 2004).

This resulted in fervent 'cultural integration' efforts, targeted at the Mizrahi immigrants by the Ashkenazi Zionist establishment. These vigorous 'melting pot' policies aimed to 'modernize', 'Israelize', and 'de-Arabize' the Mizrahi (Shohat 1989; Kimmerling 2004, 149). As Oren powerfully argues, the need to offer the Mizrahi immigrants an appropriate Zionist alternative to Arab television finally led to the emergence of a rational for the adaptation of television in the country, as the case was made that television can be used as a tool to help diminish the 'cultural gap' between the two ethnic groups (Oren 2004).

Israeli television was thus formed based on the European public service model, and put to work for the cause of producing a unified, Ashkenazi-centric Israeli identity and culture. The educational model of IETV was supposed to moderate the downward slide of Israeli culture to either American consumerism or 'Levantine' popular culture (Ibid 68). Consequently, in 1966 Israel became the first and only state to develop a fully operative educational television broadcast service, well before its general, news and entertainment service was launched (Prener Interview 8/1/2005). However, in the short period between the establishment of television and the early 1980s multiple shifts were underway and the social structures and ideologies that shaped Israeli broadcasting were rapidly changing.

Israeli sociologists and cultural critics agree that the 1980s was a watershed decade marked by a series of shifts, that transformed Israeli culture and society from the Zionist, to what is now termed, the post-Zionist era (Ram 2007). Multiple historical, structural, ideological, economical, political and cultural factors combined in triggering the shifts that were gradually eroding and dismantling the hegemonic power centres of Israeli society and the unified national identity these were sustaining.

The massive military occupation of territories and people since the 1967 ArabIsraeli war boosted the Israeli economy but at the same time fractured the Israeli national consensus. The influx of cheep migrant Palestinian workers contributed 


\section{Shabaf, Welcome to the Sitcom School...}

directly to the rise of a new, predominantly Ashkenazi Israeli middle-class, similar to its counterparts in other capitalist countries (Ben-Pora 1999). Throughout the 1970s and 1980s this new middle-class became extremely influential not only in Israeli economic life, but even more importantly in its cultural and political realms, challenging the established socialist hegemony (Ibid 171).

At the same time the late 1970s and early 1980s were for many Israelis a time of disillusionment. The euphoric mind-set brought about by the military conquests in 1967 was fracturing in the face of some dire consequences. The military oppression and economic exploitation of the occupied Palestinian territories and population, the ensuing deterioration in the Israeli-Arab conflict, and the beginning of Israeli entanglement in Lebanon in the early 1980s, made many Israelis rethink the young state's militarist ethos which was constantly justified in terms of 'self defense'.

This critical tone became increasingly prevalent in culturally elite circles as writers, academics, and film directors amongst others, took up a new ethical and political position based on resistance to the occupation (Yosef 2004). As a result Israeli politics became extremely polarized at that time - with the peace camp on the left and the 'the whole land of Israel' camp on the right. This political polarization was linked in influential ways with the growing Mizrahi-Ashkenazi tension which already had class, cultural and ethnic dimensions. This became extremely apparent during the dramatic 1977 Knesset election which brought the right-wing Likud Party to power after three decades of undisturbed Socialist Labour Party dominance. The Likud (led by Ashkenazi Jews) managed to win by mobilizing the Mizrahi vote to perceive support for its platform as a protest vote against the veteran Ashkenazi Zionist establishment, powerfully identified with the Socialist Labour Party. The political offset led to Ashkenazi hysteria and further political, ethnic, and cultural polarization. Dror Mishani (2006) describes how during the turbulent 1981 Likud re-election campaign the Mizrahi-Ashkenazi tensions violently exploded on to the streets leading the Israeli press to describe this as a crisis tearing the nation apart, as political, class, and cultural tensions aligned with the Ashkenazi-Mizrahi rift.

Additionally, after the 1973 'Yom Kippur' war, economic growth was accompanied by two important 'side effects'. First, a growth in class divisions and social inequalities as the rise in the standard of living was enjoyed mainly by the veteran Ashkenazi elite. Secondly - combined with the global oil crisis and the sharp increase in the Israeli security budget (30\% of the GNP) economic growth also lead to the development of hyperinflation. By 1984 the inflation rate reached $450 \%$. This was contributed to by Likud's irresponsible 'pre-election economics' of 1981 (Giladi, 1998). Under the motto 'benefiting the people' Prime Minister Begin lowered taxes on imported consumer goods. Interestingly television and new 
video technology played an important part in this 'campaign' as the Likud government operated to encourage the development of colour television and lower the price of colour television sets and home VCR's (Ibid).

By the 1980s Israeli society was gradually losing its sense of 'innocence' and had all but lost its pioneering fervent as new values of individualism, private enterprise and an accompanying consumer culture began to emerge. The rise of the Likud party to power accelerated the capitalization of Israel and the growing dominance of the new middle-class as its economic platform was supportive of 'reform' and liberalization. While mobilization around national goals and government centralism were still prevalent, the stage was set for the rapid economic and cultural globalization of Israel. Although the older Zionist 'pioneering' ideologies were still maintaining some mythic hold, old-guard Socialist Labour Party values and ideologies were rapidly becoming obsolete. Although central to the understanding of these processes, the role television played in these turbulent times of transformation remains severely under-examined. Nevertheless, the wider social and cultural shifts naturally manifested themselves in Israel's broadcasting system and it's quite nascent television service. They most certainly form the immediate context for IETV's sitcom production.

Drawing on oral histories by IETV professionals and rare archival materials this article will present a highly contextualized study of the processes of production and public reception of Krovim-Krovim. The exploration of the converging constraints shaping the production is instrumental in breaking away from simplistic top-down media imperialism scenarios. Instead the following analysis promotes a more nuanced understanding of seemingly 'abstract' processes of cultural globalization as they occur on and through television. By foregrounding the perspective of 'local' broadcasters, producers, and critics, this article explores the cultural significance of global television format adaptation for marginal and belated broadcast systems - like 1980s Israeli television.

\section{The Evolution of IETV}

By the 1980s IETV had developed considerably in relation to its original 1960s instructional broadcast model. Over the years the marginal television station, a sub-division of the Israeli Ministry of Education evolved considerably and with it the desire of its executives and professionals to break through its curricular constraints and non prime-time schedules, experiment with new televisual forms, and be noticed by the Israeli general audience. Although designed with a strictly instructional mandate, IETV executives were ambitious, believing they should and could compete as equals with the notoriously incompetent and awkwardly structured 'general service' of the Israeli Broadcast Authority (IBA). 


\section{Shahaf, Welcome to the Sitcom School...}

With a fraction of the IBA budget, but with a smaller more manageable and efficient production mechanism, this go-getting station finally set out and successfully beat the IBA in the race for the first family series production. However, before this could be accomplished IETV had to renegotiate its prescribed instructional raison d'être and find a way to balance its original design with its newer professional ambitions. In other words it had to find ways to broaden its target audience and its role, without violating its original nationaleducational mandate. This required a creative negotiation and reinvention of the stations goals and a redefinition of the appropriate activities for an organization still under the guardianship of the Ministry of Education.

These developments were made possible through the industrious efforts of a group of IETV executives and professionals, all devoted education people, who grew as television professionals within the organization. These leading figures were able to help IETV evolve organically, even if somewhat unexpectedly, to the point where it was able to produce the first, and to-date probably the most acclaimed full blown Israeli sitcom. Two key figures in this process were Yohanna Prener and Yaakov Lorberboim who served as IETV programme manager and general director from the early 1970s to the mid 1990s.

Prener who started her remarkable career in Israeli television as a biology teacher in the early days of IETV went on to play a crucial part in the development of commercial Israeli television. Her tenure in IETV was marked by the extraordinary successful cooperation between her and Lorberboim, who was also a veteran IETV professional, a former maths supervisor in the Ministry of Education, and a graduate of New York University's Television Studies Master's programme. Together this 'dynamic duo' formed the executive level of the organization and creatively reshaped its spirit. Fortunately I was able to interview both Prener and Lorberboim for this project, as well as Krovim-Krovim's director, Yitzhak Shauly; the show writers, Ephraim Sidon and Michael Brinson (known as B. Michael); IETV's legendary English curriculum producer Estelle Friedman, who served as production manager at the time of the show's production; and the show's set manager Michaela Laika.

Yaakov Lorberboim explained to me how over their 30 year tenure he and Prener gradually developed a wider perception of the role and target audience of IETV:

Our position was that we were not only airing for schools but this (IETV) is a cultural educational tool for the general public... which can fulfil a certain mission and influence the public beyond strictly curricular objectives. We thus started gradually changing - increasing the amount of hours broadcast and slowly targeting adults. All these things were a part of the broad perception of IETV (Interview 28/6/06). 
When I prompted him to explain whose perception this reflected and who shaped it for IETV Lorberboim responds:

That was only Yohanna and me. We presented this to the political level (the six different ministers of education we worked under over the years) because we thought it was important and we got the authorization to act accordingly...there was no need to convince anyone, since there was full faith from above in me and in Yohanna as managers (Ibid).

In an interview conducted in January 2005, four months before she sadly and prematurely passed away, Prener identified in more detail several stages and trends in IETV's development. She started by stressing that IETV was originally designed as leverage meant to transform the Israeli junior high curriculum:

The original idea was...having real teachers teaching curricular lesson plans...television broadcast was just the tip of the iceberg. It was accompanied with new books for students and teachers, and a very big umbrella teacher training (Interview 8/1/2005).

However, Prener explained that during the 1970s IETV developed from a purely instructional model to a 'softer' more generally educational 'enrichment' model. The reason for this shift was the understanding that the 'dry' classroom format ignores the televisual experience. As she put it:

In the 1970's the question was asked, where is the televisual experience? At this point there was already general television that students watch at home and we could no longer work with the assumption that television equals classroom teaching...That resulted in the development of a more humanities based cultural approach...some as part of the curriculum and some not...more relevancy, interviewing youth, reaching out to hear what they say and think... That was the 'second wave', still instructional but more inclusive more generally educational (Ibid).

Krovim-Krovim's director, Yizhak Shauly, a veteran IETV professional, explained that the shift first entailed a move, within IETV's curricular content production, away from dull, teacher-classroom sets to more sophisticated formats including elaborate stage sets and the development of scripted materials which involved characters and plots (Interview 24/7/2005). This trend accelerated and became even more crucial as the station evolved, in the late 1970s towards a new broadcast model. This next stage, which Prener identifies as the immediate context for the production of Krovim-Krovim, is the shift toward what she calls 'edutainment'. 


\title{
Welcome to the Sitcom School - IETV's 'Edutainment' Model and Krovim- Krovim
}

Prener willingly admits that IETV's sitcom venture reflected the station's desire to breakthrough its structural barriers:

\begin{abstract}
As a television station you want to do everything and to experiment with every format... we wanted to produce a sitcom because everybody else in the world was doing it. Every television station thinks that way - why do you think every Israeli channel now develops its own reality show? (Interview $8 / 1 / 2005)$
\end{abstract}

However IETV was no ordinary television station. Consequently it had to find ways to justify the production of a situation comedy in educational terms. The next step in IETV's development identified by Prener as a shift towards an 'edutainment' model became crucial in that regard. According to her, IETV's interest in reaching adult audiences, combined with the 'edutainment' shift, formed the immediate context for the creation of Krovim-Krovim. Prener explains the concept of 'edutainment' as follows:

It's a well known concept which combines education and entertainment. Thus, there is an educational thought behind what we do. You may not feel it but the people who are doing it are education people. They know what they want to do and they have defined goals. But the 'tainment' part means 'you don't have to suffer just because I am educating you' (Ibid).

This model was indeed increasingly influential in international public broadcasting in the 1980s. Singhal and Rogers (1999) call this strategy 'entertainment-education' and define it as 'the process of purposefully designing and implementing media messages to both entertain and educate, in order to increase audience knowledge about an educational issue, create favourable attitudes, and change overt behaviour' (Ibid xii). This model's popularity in the 1980s probably stems from its correspondence with the nation-building orientation typifying most television broadcast systems in 'developing' regions.

A key figure in IETV's move towards edutainment broadcasting was KrovimKrovim's producer Risha Tirman, an experienced television professional who immigrated to Israel from Poland. Tirman's first notable achievement in IETV was the creation in 1978 of the extremely popular youth magazine, Zehu-Ze (This Is It). Tirman, who worked for many years in Polish television, brought to IETV her vast televisual know-how, innovative professional vision, and impressive organizational skills. Writer Ephraim Sidon, who was involved in both Zehu-Ze and Krovim-Krovim, emphasises the role played by Tirman in the production that revolutionized IETV's schedule: 
IETV at that time broadcast programmes teaching biology and grammar...suddenly Tirman came and brought things they never dreamed of, a youth magazine broadcast live in the afternoon...It became extremely popular and attracted both children and adults...it was supposed to be educational...but pretty soon became more and more entertaining. The attraction was the intermediate sketches, between which you had somewhat educational contents (Interview 30/12/ 2005).

Although the elderly producer was unfortunately unavailable for interview for this study, her character nonetheless looms large. All those involved describe her as 'a powerhouse' and a 'bulldozer' - the definite generating figure behind the idea for and subsequent success of Krovim-Krovim. The success of Zehu-Ze convinced Tirman, Prener and Lorberboim that IETV was ready to produce an original series based on the globally popular sitcom formula. Drawing on the new 'edutainment' model the first step in the production of the first Hebrew sitcom was the careful development of what director Shauly humorously calls the show's 'educational alibi'.

Interestingly the issues addressed in this organizational discourse are highly compatible with the concerns at the heart of the problem-solution model that propelled Israeli broadcasting in the first place. As Lorberboim puts it when asked about the motivations for the production of the show:

We were a dynamic station, whose concern was to recognize the needs of the state of Israel... and try to provide for these needs. The state of Israel, may God bless it, has many problems it will stand with for many years. (Interview 28/6/2006)

The turbulent Israeli reality of the early 1980s provided ample social problems for IETV to tackle in its sitcom production. The ethnic tensions between Mizrahim and Ashkenazim played pivotal part in this, as well as the need to deal with rapidly changing social and economical realities and a subsequent shift in national values. As Prener puts it:

Yaakov and I were both worried by ... the social tensions between different
sectors and ethnic groups in the country, the dismantling of the classic
family....we always thought that the social direction of Israel is so dramatic,
and it takes Israel to a place of weakness instead of a place of strength and
pleasure. But what can television do here? (Through formats such as the
sitcom) television can look at things with a different eye, with humour, with
sympathy and still create empathy (Interview $8 / 1 / 2005$ ).

In other words, IETV was justifying the production of a sitcom in terms of Israeli broadcasting's fundamental social task - the need to help unify the people of Israel and gloss over social rifts and cultural gaps. This quote begins to demonstrate the 


\section{Shahaf, Welcome to the Sitcom School...}

interesting ways in which IETV's particular national-educational raison d'être colours the station executives' perception of the sitcom format.

Quite remarkably in her discussion of the sitcom's advantages Prener refers simultaneously to domestic sitcoms like Happy Days and 'turn to relevance' sitcoms like All in the Family. Her discussion of these extremely different shows sheds light on the process through which IETV came to view the format's potential from the perspective of their own national mission. Prener's analysis of the abovementioned shows combines enthusiasm regarding the first, humorously tackling familial parent-child issues, with praise for the latter's engagement with and alleviation of ethnic and social tensions. Of course Prener is aware that IETV's production was much more conservative than Norman Lear's biting satire. However she nevertheless takes pride in the fact that:

Unlike All in the Family where the African-Americans are excluded from the family as neighbours, Krovim-Krovim had mixed or integrated MizrahiAshkenazi families (Ibid).

Thus, although by producing a sitcom IETV was seemingly departing from its prescribed national-educational mandate, its executives and professionals were very much invested in maintaining and demonstrating their commitment to the organization's established raison d'être. While admittedly looking to adapt the sitcom format to be more competitive in a progressively globalizing televisual environment, marked by the dominance of U.S. and U.K entertainment formats, they were utilizing the popular formula for their own ends, by taking on Israel's pressing social problems.

The following section will sketch the careful balancing act of the Krovim-Krovim production as it struggled to fulfil and negotiate these two, seemingly contradictory but in fact intertwined set of constraints - the development of a series that would 'serve the needs of the people of Israel' as understood by the paternalistic-public IETV, but would still adhere as closely as possible to the aesthetic and stylistic demands of the adapted sitcom formula.

\section{The Chronicles of Krovim-Krovim - The Making of an Educational Sitcom}

While Prener and Lorberboim openly discuss IETV's motivation in nationaleducational terms, other agents involved in the production are ambivalent or even dismissive in relation to the show's educational goals. Most unequivocal in this regard are the shows co-writers B. Michael and Ephraim Sidon who vehemently deny it had any prescribed educational goals. When confronted with contradicting evidence B. Michael sarcastically explained: 
In big systems, especially ones with the title educational attached, there is a tendency to wrap everything with...professional bullshit. It could be (that Prener) had enough papers to demonstrate all we did was very educational. I'm sure they had endless seminars and...brought in advisers from 400 countries, with beautiful ideas on how this show will solve the problems of the people of Israel. I couldn't care less, I don't give a shit, and I have never seen all these things...We treated with forgiving ridicule the declaration that...we were producing an educational show, no, we were making a sitcom and it was well known to everyone involved (Interview 29/7/ 2005).

Of course Michel is absolutely right in his statement that everyone in IETV knew they were working on a sitcom. Nevertheless, IETV executives did spend much time carefully crafting the format for the show in order to represent their nationaleducational vision. When asked about the writers responses Prener amusingly explained that:

We didn't burden them with the educational goals; we wanted them to write
funny scripts ... We had some sort of social thought behind the televisual
concept. Later on you have camouflage processes, in the writing, in the
humour, but it does not matter. The spirit of things always comes from the
concept and later on things evolve (Interview $8 / 1 / 2005$ ).

These fissures thus reveal the subtle negotiations of 'educational' and 'entertainment' goals constructing the production process.

The person most responsible for balancing these two sets of constraints was Krovim-Krovim's producer Risha Tirman. Prener explains that Tirman who had 'both an educational agenda and a professional-televisual agenda' was 'the executing authority' in the production process. It was the skilled producer's know-how that enabled her, according to Prener, to 'direct matters in such a way as to balance the demands of both educational and professional production needs, as she was involved in both dimensions' (Ibid). This corresponds to Newcomb and Alley's (1983) famous argument that television is a 'producers' medium' where the universal responsibility for both the show's creative vision and its adherence to industrial or organizational constraints, lies squarely on the producer's shoulders.

Tirman's ability to navigate IETV's particular constraints is demonstrated in a memo she wrote before the final decision to produce the show was made (Shauly production files 6/3/1981). In this memo, addressed to Lorberboim and Prener, Tirman outlines the show's educational goals and establishes the importance of its entertaining format. The first stated goal is 'the presentation of a typical (ethnically integrated) Israeli family, as a social unit responsible for its individual destiny and for the destiny of the nation'. The composition of the family Tirman explains 'will reflect the problems of ethnic integration', and thus 'apart from internal familial 


\section{Shahaf, Welcome to the Sitcom School...}

problems the show will relate to external and social problems that can be related to current issues' such as 'the economy and...ethnic problems'. The memo ties the proposed series' entertaining format to these educational goals as follows: 'despite the serious nature of these problems the nature of the show should be light and humorous and all the problems are solved like in happy families, where sentiment helps overcome difficulties' (Ibid). As Prener explains:

There were certain messages that we wanted to convey through the format
of the show. Because of these messages we built... the different social fabric
that the characters belonged to... the idea was to have characters that come
from different backgrounds... We wanted a representation of an Israeli
family that would help assuage some of the social tensions... (Interview
$8 / 1 / 2005$ ).

Documents found in Shauly's production files verify that all pre-production processes including the finalization of the format for the show, storylines and character development, involved extensive reliance on the advice of academic experts. As the reports show, these experts - namely psychologists, social scientists, and education scholars - were asked to suggest potential contents for the show, based on 'national, and universal educational concerns' as well as to comment on their potential for 'comic presentation'. A good example is a paper written by psychologist Dr. Amiram Raviv who served as an advisor for the show from its inception, participating in script meetings with the writers, Tirman and Shauly (Interview 24/7/2005; B. Michael in Ohad 1983). In his report Raviv suggests a host of ideas for the show's content 'based on professional psychological material, social scientific research reports, personal knowledge, professional experience, and personal contemplation'. The suggestions he made emphasized the importance of such topics as ethnic integration, and 'general national problems' like security, the economy and the Israel-Arab conflict.

On top of this the production team's preparation work included thorough learning of the professional and technical televisual aspects involved in sitcom production. The production team was heavily committed to fulfilling the demands of the adapted formula and producing an adequate rendition. Shauly believed that the success of the show depended on a careful learning process and as accurate as possible implementation of the 'original' production practices:

If you take on a model you have to implement it, from a production perspective, as fully as possible. We talked about producing a 'proper' sitcom and ...said that whatever happens we will try our best to do it in front of a live studio audience like they do in the U.S. (Interview 24/7/2005).

However, they first had to find a way to learn the practices and strategies involved in such a production. In a similar vein to the work carried out on the programme's 
educational aspects, IETV reached out to a range of experts. Documents found in Shauly's files reveal that Tirman was soliciting American experts for consultation on script writing and production practices and as previously noted these efforts culminated in the production team's journey to the U.S. for training on the set of Three's Company. In a statement that sheds light on IETV's perception of the distinction between form and content in format adaptations Shauly explains:

We didn't know anything about that show, but it was not important at all because we didn't need it as an example for what we wanted to do, but more of an example for how we should organize ourselves strategically. It could have been anything as far as we were concerned as long as it's going to be a sitcom shot in front of a live studio audience (Ibid).

Shauly, Prener and Tirman spent some time on the Los Angeles set, talked to the producers of Three's Company, observed the production practices, and attended script meetings. Prener shamefully admits it was 'horrible chutzpah' on their part that enabled such access (Interview 8/1/2005). Upon their return the crew faced the challenges of implementing what they had learned with the limited financial and human resources available to them. Prener described the experience as extremely disheartening:

I was devastated. I didn't think we could do it. I thought 'the studio is way too small. The actors, who are trained in theatre, wouldn't be able to keep up with the pace of TV acting...I can't give this production the one IETV studio for four days'...Then we started working it out. One price was we did half the number of shows per year. Another...that the audience was tortured and we could barely have 50 people...it was hard to fit three sets into the studio so we had to be creative in building them (Ibid).

As set designer Michele Laika explained the challenges were so daunting that she 'was crying for a whole year' (Interview 9/7/2007). However, she tells an interesting story when, after finally figuring out a series of creative solutions for the set design, she presented them to some BBC consultants who were visiting IETV. When the distinguished guests were shown into the studio - where three sets were built in each corner of the room and the fourth corner was allocated for the live audience with cameras rotating to shoot each scene from the adjacent set - they applauded this creativity saying:

From our 'macro' perspective we wouldn't have been able to come up with these amazing micro solutions... We would have simply given up on it as 'mission impossible' (Ibid).

As I have already demonstrated in the opening of this article the micro/macro framework is extremely prevalent in both the production and public reception discourses surrounding Krovim-Krovim. Significantly the producers of the show 


\section{Shabaf, Welcome to the Sitcom School...}

often used this framework not only in interviews conducted for this study, but also in their press interviews in the 1980's. For example when discussing IETV's space constraints with reporter Naomi Gal, Tirman mentions the production teams' trip to America where they saw 'mega-studios dedicated solely for the recordings of such shows...Outside of Israel', she assures Gal, '...they would use a studio that small as a bathroom' (Gal 1983, 16). On the same topic writer B. Michael told the Haaretz journalist and critic Michael Ohad, 'every time I see Benson open doors and move freely between rooms my heart fills with envy - I want a set like that too!' (Ohad 1983, 53). In a different interview with Aviv Hebron, Tirman states, 'in the conditions we have here, even if we are as talented as our colleagues overseas, from the beginning we have worked with one hand tied behind our back' (Ibid 34).

\section{Conclusion}

As I have shown, the discourses surrounding the production process and public reception of Krovim-Krovim continuously position Israel as marginal in a transnational televisual field. What emerges here is the profound interconnectedness between the allegedly opposed 'local' and 'global' dimensions involved in the cultural debates surrounding the show's production and public reception. Thus, this study begins to reveal how 'local' cultural identity is powerfully constructed through the hybrid negotiations involved in global format adaptation. In this formal 'domestication' process local identity is constructed through both 'positive' and 'negative' assertions. On the one hand through the development of Krovim-Krovim's specific format, IETV asserts its perception of 'adequate' Israeli cultural representation as shaped by the constraints of a nationaleducational broadcast home. On the other hand there is a constant sense of marginality involved as producers struggle to come up with a competitive product that would live up to the standards dictated by the dominant U.S and U.K imports. This is enhanced as critics, and, undoubtedly, audiences also use these models as a yardstick for their evaluation of the local series.

The nostalgic attachment of many Israelis to Krovim-Krovim testifies to the fact that in this particular case the team struck a chord as it utilized a globally popular televisual formula to produce a cultural artefact which is uniquely Israeli. Nonetheless it is uniquely Israeli exactly because it represents the cultural negotiations of global and local forces shaping the national experience of the time. Thus, ultimately, I argue that this very process of multivalent cultural negotiation is, in fact, how globalization happens. In other words, globalization is neither external nor is it simplistically 'enforced' on marginal societies 'from above' by the 'advent' of dominant economic forces. Rather, globalization occurs locally 'on the ground', in a very concrete manner as real people, in this case IETV producers working on the production of the first Israeli sitcom, negotiate a given set of 
organizational, ideological, technical, and cultural constraints and the contradictory yet intertwined goals they dictate. This does not in any way preclude the dominance of the Western influence thus negotiated. Thus, the study of television 'local' format adaptation, not only in contemporary commercial environments but also in historical and public broadcasts, is extremely helpful for the contextualized exploration of the historical processes of globalization.

\section{Notes}

${ }^{1}$ IBA produced at least two game shows modelled on American formats. I've Got a Secret (Ze HA Sod Sheli, 1975-1980) and Hollywood Squares (Tesha Ba Ribua, 1977-1982). They also produced a local version of the British This is Your Life (Haim she kaele, 1967-2000). However they did not produce a multi-seasonal fictional dramatic format until 1989. Indeed, to this day no sitcom has surpassed the success and status of IETV's Krovim Krovim. 2 All quotes from the Israeli press, as well as subsequent quotes from interviews conducted for this study are translated by the author from the original Hebrew.

3 'Goyim Naches' literally in Yiddish 'games gentiles (non Jews) play' or foreign pleasures Daniel Boyarin explains this as a term of opprobrium used by traditional European Jewish society to describe European Christian culture and its 'masculine' values such a war-making, duelling, and adulterous courtly love affairs (Boyarin 1997, 38).

\section{References}

Almog, O. (2004) Farewell to 'Srulik'- Changing V alues Among the Israeli Elite, Haifa: Haifa University Press.

Barber, B. (1995) Jihad vs. McWorld: How Globalism and Tribalism are Shaping the World, New York: Times Books.

Caspi, D. and Y. Limor (1992) The Mediators: The Mass Media in Israel 1948-1990, Tel Aviv: Am Oved.

Gal, N. (1983) 'The House In Nine Vitek St', Yediot Aharonot, January 28, p.16.

Giladi, D. (1998) Israeli Economy, Development, Characteristics Policy, Jerusalem: The Israeli Ministry of Education Press.

Hall, S. (1997) 'Old and New Identities, Old and New Ethnicities' in A.D.King

(ed.) Culture, Globalization and the World System, University of Minnesota Press, pp 41-68.

Hebron, A. (1983) 'Krovim-Krovim', Koteret Rashit, January 1, pp 34-35.

Keane, M.(2006) 'Once Were Peripheral: Creating Media Capacities in East Asia', Media, Culture and Society, 28(6): 835-855.

Keane, M., A. Fung and A. Moran (2007) New Television, Globalization and the Asian Cultural Imagination, Hong Kong: Hong Kong University Press.

Keisari, G. (1983) 'Blue and White Bubbles'. Maariv, February 3, pp 3.

Kellner, D. (2002) 'Theorizing Globalization', Sociological Theory, 20 (3): 285305.

Kimmerling, B. (2004) Immigrants, Settlers, Natives - the Israeli State and Society Between Cultural Pluralism and Cultural Wars, Tel Aviv: Am Oved 
Shabaf, Welcome to the Sitcom School...

Publishers.

Mishani, D. (2006) The Ethnic Unconscious - The emergence of 'Mizrahiu't in the Hebrew Literature of the Eighties, Tel Aviv: Am Oved.

Moran, A. (1998) Copycat TV-Globalization, Program Format and Cultural

Identity, Luton: University of Luton Press.

Moran, A. and J. Malbon (2006) Understanding the Global TV Format, Bristol:

Intellect.

Navarro, V. (2006) 'Television, Globalization, and the popularity of Formatted Programs', Response paper for roundtable discussion on Globalizing Television Studies, Flow conference, Austin, Texas, U.S.A 27-29 October, 2006.

Newcomb H. and A. Robert (1983) The Producers' Medium-Conversations with the creators of American TV, New York and Oxford: Oxford University Press.

'Campaign for Reunion Episode of Krovim-Krovim Accelerates', available at http://www.ynet.co.il/articles/0,7340,L-2901330,00.html (accessed 11 April 2007)

Ohad, M. (1982) 'In the Best Families' Ha'aretø, December 10, p.16.

Oren, T. G. (1999) 'Living Room Levantine: Immigration, Ethnicity and the Border in Early Israeli Television', Velvet Light Trap, 44 (2): 20-30.

Oren, T. G. (2004) Demon in the Box-Jews, Arabs, Politics, and Culture in the Making of Israeli Television, New Brunswick, New Jersey and London: Rutgers University Press.

Oren, T. G. and Shahaf, S. (forthcoming) 'Editors Introduction' In Global Television Formats, New York: Routledge.

Ram, U. (1995) The Changing Agenda of Israeli Sociology: Theory, Ideology and Identity, New York: SUNY Press.

Ram, U. (2007) The Globalization of Israel: McWorld in Tel Aviv; Jihad in Jerusalem, New York and London: Routledge.

Regev, E. And M. Seroussi (2004), Popular Music and National Culture in Israel, Berkeley: University of California Press.

Schiller, H. (1992) Mass Communication and American Empire, Boulder: Westview Press.

Shapir, G. and Y. Peled (2005) Being Israeli the Dynamics of Multiple Citizenship, Tel Aviv: Tel Aviv University Press.

Singhal, A. and E.M. Rogers (1999) Entertainment-Education - A Communication Strategy for Social Change, London, New Jersy: Lawrence Erlbaum Associates.

Sreberny-Mohammadi, A., D. Winseck, J. McKenna and O. Boyd-Barrett (eds.) (1997) Media in Global Context: A Reader, London: Hodder Arnold.

Waisbord, S. (2004) 'McTV - Understanding the Global Popularity of television Formats', Television and New Media, 5 (4): 359-383. 